doi: https://doi.org/10.15407/microbiolj83.02.020

\title{
SYNTHESIS AND BIOLOGICAL ACTIVITY OF ACINETOBACTER CALCOACETICUS IMV B-7241 SURFACTANTS DEPENDING ON MONOVALENT CATIONS CONTENT IN CULTIVATION MEDIUM
}

\author{
T.P. Pirog ${ }^{1,2}$, D.A. Lutsai ${ }^{1}$, T.A. Shevchuk ${ }^{2}$, G.O. Iutynska ${ }^{2}$ \\ ${ }^{1}$ National University of Food Technologies, \\ 68 Volodymyrska Str., Kyiv, 01601, Ukraine \\ ${ }^{2}$ Zabolotny Institute of Microbiology and Virology, NAS of Ukraine, \\ 154 Acad. Zabolotny Str., Kyiv, 03143, Ukraine \\ e-mail:tapirog@nuft.edu.ua
}

\begin{abstract}
Microbial surfactants (biosurfactants) are multifunctional preparations due to a combination of physicochemical (reduction of surface and interfacial tension, emulsifying activity) and biological (antimicrobial and antiadhesive activity, the ability to destroy biofilms) properties. However, the disadvantage of biosurfactants synthesized as a complex of compounds is the possibility of changing the biological activity depending on the conditions of producer cultivation. Aim. To study the effect of potassium and sodium cations on the $\mathrm{NADP}^{+}$-dependent glutamate dehydrogenase activity of cell-free extract of Acinetobacter calcoaceticus IMV B-7241 with subsequent appropriate modification of the nutrient medium composition and determination of antimicrobial and anti-adhesive activity of surfactant synthesized. Methods. A. calcoaceticus IMV B-7241 strain was grown in media containing 2\% of sunflower oil waste as a carbon source, as well as various concentrations of potassium and sodium chloride (basal - $1.0 \mathrm{~g} / \mathrm{l} \mathrm{NaCl}$, medium \# 1 that did not contains $\mathrm{NaCl}$, medium \# 2 in which the concentration of $\mathrm{NaCl}$ was $2.0 \mathrm{~g} / \mathrm{l}$, medium \# 3 in which the concentration of $\mathrm{NaCl}$ and $\mathrm{KCl}$ was $1.0 \mathrm{~g} / \mathrm{l} \mathrm{each).} \mathrm{The} \mathrm{surfactants}$ were extracted from the supernatant liquid culture with a modified Folch mixture. Anti-adhesive activity and the degree of biofilms degradation were determined by spectrophotometric method, antimicrobial activity - by the indicator of the minimum inhibitory concentration (MIC). Activity of enzymes of surface-active aminolipids biosynthesis (NADP ${ }^{+}$-dependent glutamate dehydrogenase) and glycolipids (phosphoenolpyruvate (PEP) carboxylase, PEP-synthetase, PEP-carboxykinase, trehalose phosphate synthase) were analyzed in cell-free extracts obtained after the destruction of cells by ultrasound. Results. It was found that potassium and sodium cations in concentrations of 50 and $100 \mathrm{mM}$ are inhibitors of $N A D P^{+}$-dependent glutamate dehydrogenase, and in lower concentrations (5-20 mM) - activators of this enzyme, as well as PEP-carboxykinase and PEP-synthetase. The increase in the biosurfactant concentration to 6.1-7.7 g/l during cultivation of A. calcoaceticus IMV B-7241 in medium \# 1 and \# 3 was due to the predominant synthesis of glycolipids under such conditions, which was evidenced by the increase in 1.8-6.5 times in the activity of PEP-carboxylase, PEP-carboxykinase, PEP-synthetase and trehalose phosphate synthetase compared to the indicators on the basal medium. The concentration of surfactants synthesized in the basal medium was $3.6 \mathrm{~g} / \mathrm{l}$, but such surfactants were characterized by the highest antimicrobial and anti-adhesive activity. Their MIC against the test-cultures of studied bacteria (Pseudomonas sp. MI-2, Bacillus subtilis BT-2, Escherichia coli IEM-1, Staphylococcus aureus BMS-1, Enterobacter cloaceae C-8) and fungi (Candida albicans D-6, Rhizopus nigricans P1, Aspergillus niger $P-3$, Fusarium culmorum T-7) were $0.88-56 \mu \mathrm{g} / \mathrm{ml}$ and were by 2-3 orders of magnitude lower compared to established for surfactants synthesized in modified media \# 1-3. In the case of treatment of abiotic materials with surfactant solutions obtained on the basal medium, the adhesion of bacteria and fungi was on average 10-20\% lower than after surface treatment by the surfactant synthesized in modified media. In the presence of 148-296 $\mu \mathrm{g} / \mathrm{ml}$ of surfactants obtained in the basal medium, destruction of S. aureus BMS-1 and B. subtilis BT-2 biofilms was 45-66\%, and C. albicans D-6 yeast-39-44\%. Under the action of similar concentrations of surfactants synthesized in modified media, the destruction of bacterial and yeast biofilms was lower: 6-52 and 20-46\%, respectively. Conclusions. The obtained results are consistent with the data of our previous studies on the possibility of regulating the antimicrobial and anti-
\end{abstract}


adhesive activity of surfactants in the process of producer cultivation by changing the content of cations in the medium, which are inhibitors/activators of enzymes responsible for the synthesis of components of the surfactants complex, which have certain biological properties.

Keywords: Acinetobacter calcoaceticus IMV B-7241, surfactants, potassium and sodium cations, biological activity, biosynthesis.

Despite the fact that today the industrial production of microbial surfactants is limited to a dozen campaigns, the interest of researchers in these multifunctional products is increasing every year [1].

In comparison with known antimicrobial and anti-adhesive agents, biosurfactants have a number of advantages [2-4]: biodegradability and nontoxicity, which prevents contamination of the environment and the manifestation of allergic reactions, as well as the possibility of using them in a wide range of $\mathrm{pH}$, temperature and other external factors, this is due to the stability of physical and chemical properties. At the same time, the mechanism of biosurfactants action consisting in the violation of the integrity of the cytoplasmic membrane reduces the possibility of occurrence of resistant forms of microorganisms.

Nonetheless, one of the disadvantages of biosurfactants (then, as other secondary metabolites synthesized in the form of a complex of similar compounds) is the possibility of changing biological properties under various conditions of producer cultivation. However, until recently, this problem remained outside the attention of researchers. Only last year's works have there been on the correlation between the chemical composition and the properties of biosurfactants, which have been analyzed and summarized by us in the review [5]. The available literature suggests the possibility of regulating the antimicrobial activity of biosurfactants only chemically or as a result of the improvement of producer strains by genetic or metabolic engineering. The results of our research presented in the review [5] showed that there is a simpler and no less effective way to regulate the biological properties of surfactants in the process of cultivating a producer on a modified medium containing activators of enzymes responsible for the synthesis of surfactants complex components with certain necessary properties.

Thus, in Acinetobacter calcoaceticus IMV B-7241 the key enzyme of aminolipids biosynthesis responsible for the antimicrobial activity of surfactants is $\mathrm{NADP}^{+}$-dependent glutamate dehydrogenase [6], which is activated by calcium and magnesium cations. An increase in the concentration of activators in the producer's cultivation medium was accompanied by increasing the antimicrobial and anti-adhesive activity of the synthesized biosurfactants.

Solitary literature and our own experimental data indicate that the activity of $\mathrm{NADP}^{+}$-dependent glutamate dehydrogenase in microorganisms increases in the presence of monovalent cations [7-9].

In this regard, the aim of this study is to investigate the effect of potassium and sodium cations on the $\mathrm{NADP}^{+}$-dependent glutamate dehydrogenase activity of cell-free extract of A. calcoaceticus IMV B-7241 with subsequent appropriate modification of the nutrient medium composition and determination of antimicrobial and anti-adhesive activity of synthesized surfactants.

Materials and methods. The main object of research was a strain of oil-oxidizing bacteria isolated from an oil-contaminated soil sample and identified as Acinetobacter calcoaceticus K-4 [10]. A. calcoaceticus $\mathrm{K}-4$ strain is registered in the Depository of Microorganisms of the D.K. Zabolotny Institute of Microbiology and Virology of the National Academy of Sciences of Ukraine under the number IMV B-7241.

Bacterial (Pseudomonas sp. MI-2, Bacillus subtilis БТ-2, Escherichia coli IEM-1, Staphylococcus aureus 5MC-1, Enterobacter cloaceae C-8) and fungal (Candida albicans Д-6, Rhizopus nigricans P1, Aspergillus niger P-3, Fusarium culmorum T-7) strains from the collection of live cultures of the Department of Biotechnology and Microbiology of the National University of Food Technologies were used as test cultures in determining the antimicrobial and antiadhesive activity of surfactants, as well as their role in the destruction of biofilms.

A. calcoaceticus IMV B-7241 strain was grown in a liquid mineral medium of the following composition $(\mathrm{g} / \mathrm{l})$ : $\left(\mathrm{NH}_{2}\right)_{2} \mathrm{CO}-0.35, \mathrm{NaCl}-$ 1.0, $\mathrm{Na}_{2} \mathrm{HPO}_{4} \cdot 12 \mathrm{H}_{2} \mathrm{O}-0.6, \mathrm{KH}_{2} \mathrm{PO}_{4}-0.14$, $\mathrm{MgSO}_{4} \cdot 7 \mathrm{H}_{2} \mathrm{O}-0.1$, distilled water-up to 11 , $\mathrm{pH}$ 6.8-7.0. A yeast autolysate $-0.5 \%$ (volume fraction) and a micronutrient solution $-0.1 \%$ (volume fraction) containing (g/100 ml): $\mathrm{ZnSO}_{4} \times$ 
$\times 7 \mathrm{H}_{2} \mathrm{O}-1.1 ; \mathrm{MnSO}_{4} \times \mathrm{H}_{2} \mathrm{O}-0.6 ; \mathrm{FeSO}_{4} \cdot 7 \mathrm{H}_{2} \mathrm{O}-$ $0.1 ; \mathrm{CuSO}_{4} \times 5 \mathrm{H}_{2} \mathrm{O}-0.004 ; \mathrm{CoSO}_{4} \times 7 \mathrm{H}_{2} \mathrm{O}-0.03$; $\mathrm{H}_{3} \mathrm{BO}_{3}-0.006$; $\mathrm{Ki}-0.0001$; EDTA (Trilon B) -0.5 were also additionally added to the medium (basal medium).

Cultivation of the IMV B-7241 strain was also carried out in the basal medium without $\mathrm{NaCl}$ (medium \# 1), in which the $\mathrm{NaCl}$ concentration was $2.0 \mathrm{~g} / 1$ (medium \# 2), in which an additional $1.0 \mathrm{~g} / 1 \mathrm{KCl}$ (medium \# 3) was added.

Waste sunflower oil after frying potatoes was used as a source of carbon and energy at a concentration of $2 \%(\mathrm{v} / \mathrm{v})$. Inoculum was a culture in the middle of the exponential growth phase, grown in the basal medium with $0.5 \%$ $(\mathrm{v} / \mathrm{v})$ of waste oil. The amount of inoculum $\left(10^{4}-10^{5}\right.$ cells $\left./ \mathrm{ml}\right)$ was $5 \%$ of the mediums volume. Cultivation was carried out in $750 \mathrm{ml}$ flasks with $100 \mathrm{ml}$ of medium on a shaker $(320 \mathrm{rpm})$ at $30^{\circ} \mathrm{C}$ for 120 hours.

The amount of extracellular surfactants was determined using our modified method of Bligh and Dyer after extraction with a mixture of chloroform and methanol (2:1) from the supernatant of the culture liquid as described in the study [11]. To obtain the supernatant, the culture liquid was centrifuged at $5000 \mathrm{~g}$ for 20 minutes.

The antimicrobial activity of surfactants was analyzed by the minimum inhibitory concentration (MIC) index. The definition of MIC was carried out by dual-fold serial dilutions in meat-peptone broth (MPB) for bacteria and liquid wort for fungi, as described earlier $[6,9]$. The results were evaluated visually by the medium turbidity: $(+)$ - tubes in which the turbidity of the medium was observed (growth of the testing culture), $(-)$ - there was no turbidity (no growth). The MIC of the surfactant solution was defined as the concentration of surfactants in the last tube where growth was absent.

The anti-adhesive activity of surfactants was determined as described in our previous paper [6]. The number of adhering cells (degree of adhesion) was determined by spectrophotometric method as the ratio of the extinction of the suspension obtained from materials treated with surfactant preparations (tile, steel, glass, polystyrene) to the extinction of control samples (without surfactant treatment) and expressed as a percentage.

Studies of the effect of surfactants on biofilm destruction were carried out as described in our paper [6]. $200 \mu \mathrm{l}$ of surfactant preparations of various concentrations were added to the wells of the polystyrene microplate with the test-culture biofilm previously formed on them, after $24 \mathrm{~h}$ of exposure the wells were washed three times with $200 \mu \mathrm{l}$ of distilled water and the number of adherent cells was determined by spectrophotometric method. The degree of biofilm destruction (\%) was defined as the difference between cell adhesion in untreated and treated by surfactants wells of polystyrene plate.

To obtain cell-free extracts, the culture liquid was centrifuged $\left(5000 \mathrm{~g}, 20 \mathrm{~min}, 4{ }^{\circ} \mathrm{C}\right)$. The resulting cell precipitate was washed twice from medium residues with $0.05 \mathrm{~mol}$ of $\mathrm{K}^{+}$-phosphate buffer (pH 7.0), centrifuged $\left(4000 \mathrm{~g}, 15 \mathrm{~min}, 4^{\circ} \mathrm{C}\right.$ ). The washed cells were resuspended in $0.05 \mathrm{~mol}$ of $\mathrm{K}^{+}$-phosphate buffer ( $\mathrm{pH} 7.0$ ) and destroyed by ultrasound $(22 \mathrm{kHz}) 3$ times for $20 \mathrm{~s}$ at $4{ }^{\circ} \mathrm{C}$ on an UZDN-1 device. The resulting disintegrate was centrifuged $\left(12000 \mathrm{~g}, 30 \mathrm{~min}, 4{ }^{\circ} \mathrm{C}\right)$, the precipitate was separated, and the supernatant was used for further studies as a cell-free extract.

The activity of the enzymes was determined as described in our study [12]. The activity of phosphoenolpyruvate (PEP) synthetase (EC 2.7.9.2) was determined by the rate of pyruvate formation, which was analyzed by NADH oxidation at $340 \mathrm{~nm}$ in a conjugated reaction with lactate dehydrogenase, PEP-carboxykinase (EC 4.1.1.49) by the formation of PEP and pyruvate during NADH oxidation, and glutamate dehydrogenase (EC 1.4.1.4) - by formation of glutamate during NADPH oxidation at $340 \mathrm{~nm}$, PEP-carboxylase (EC 4.1.1.31) - after NADPH oxidation at $340 \mathrm{~nm}$. The activity of trehalose phosphate synthase (EC 2.4.1.15) was analyzed by the formation of uridine diphosphate, which was determined spectrophotometrically by the oxidation of NADH at $340 \mathrm{~nm}$ in conjugated reactions with pyruvate kinase and lactate dehydrogenase.

When studying the effect of monovalent cations on $\mathrm{NADP}^{+}$-dependent glutamate dehydrogenase activity, 5-100 $\mathrm{mM} \mathrm{K}^{+}$or $\mathrm{Na}^{+}$was added to the reaction mixture as a solution of $\mathrm{KCl}$ and $\mathrm{NaCl}$ salts.

The enzyme activity was expressed in nmol of the product per $1 \mathrm{~min}$ of reaction per $1 \mathrm{mg}$ protein. The protein content in cell-free extracts was determined by Bradford. The activity of the enzymes was analyzed at $28-30{ }^{\circ} \mathrm{C}$ - the temperature optimal for A. calcoaceticus IMV B-7241 growth.

All experiments were performed in triplicate; the number of parallel determination in the experiments was $3-5$. Statistical processing of experimental data was carried out as described in 
previous papers $[6,9]$. The differences in averages were considered reliable at the level of significance $\mathrm{p}<0.05$.

Results. At the first stage, the enzymes activity of surface-active aminolipids biosynthesis (NADP ${ }^{+}$-dependent glutamate dehydrogenase) and glycolipids (PEP- synthetase and PEPcarboxykinase) in cell-free extract $A$. calcoaceticus IMV B-7241 was analyzed depending on the concentration of monovalent cations in the reaction mixture (Table 1). It was found that potassium and sodium cations at concentrations of 50 and $100 \mathrm{mM}$ are inhibitors of $\mathrm{NADP}^{+}$-dependent glutamate dehydrogenase, and in the presence of lower concentrations ( 5 and $10 \mathrm{mM} \mathrm{Na}^{+}$, 20 and $30 \mathrm{mM} \mathrm{K}^{+}$), a 2-fold increase in the activity of this enzyme was observed compared to that without monovalent cations. The introduction of monovalent cations in the reaction mixture at a concentration of 5-20 mM was accompanied by an increase in PEP-carboxykinase and PEP-synthetase activity.

The data on the concentration of surfactants synthesized during cultivation of $A$. calcoaceticus IMV B-7241 in media with different content of monovalent cations are presented in Table 2. The highest amount of surfactants was observed when growing producer in medium \# 1, which did not contains potassium and sodium cations, and medium \# 3, in which the concentration of $\mathrm{KCl}$ and $\mathrm{NaCl}$ was $1 \mathrm{~g} / 1$. During cultivation of A. calcoaceticus IMV B-7241 on the basal medium and medium \# 2, in which only sodium cations as monovalent are present, the surfactant concentration was significantly lower (3.6 and $2.4 \mathrm{~g} / 1$, respectively).

At the next stage, the enzymes activity of surface-active amino- and glycolipids biosynthesis during $A$. calcoaceticus IMV B-7241 cultivation in the basal and modified media \# 1-3 was determined (Table 3).

Table 1

The effect of different concentrations of monovalent cations on key enzymes activity of surface-active amino- and glycolipids biosynthesis of $A$. calcoaceticus IMV B-7241

\begin{tabular}{|l|c|c|c|c|}
\hline \multirow{2}{*}{$\begin{array}{l}\text { Monovalent } \\
\text { cations }\end{array}$} & \multirow{2}{*}{$\begin{array}{c}\text { Concentration in the } \\
\text { reaction mixture, } \mathrm{mM}\end{array}$} & $\begin{array}{c}|c| \\
\text { NADP } \\
\text { glutamate dehydrogenase }\end{array}$ & PEP-carboxykinase & PEP- synthetase \\
\cline { 3 - 5 } & 5 & $\mathbf{3 8 5} \pm 19$ & $\mathbf{3 8 5} \pm 19$ & $\mathbf{1 2 3 0 8} \pm 615$ \\
\cline { 2 - 5 } & 10 & $\mathbf{3 8 5} \pm 19$ & $\mathbf{5 7 7} \pm 29$ & $10000 \pm 500$ \\
\cline { 2 - 5 } & 20 & $192 \pm 10$ & $\mathbf{7 6 9} \pm 39$ & $9808 \pm 490$ \\
\cline { 2 - 5 } $\mathrm{Na}^{+}$ & 30 & $192 \pm 10$ & $192 \pm 10$ & $7500 \pm 375$ \\
\cline { 2 - 5 } & 50 & $160 \pm 8$ & $\mathrm{n} / \mathrm{d}$ & $\mathrm{n} / \mathrm{d}$ \\
\hline \multirow{5}{*}{$\mathrm{K}^{+}$} & 100 & $107 \pm 5$ & $\mathbf{n} / \mathrm{d}$ & $\mathrm{n} / \mathrm{d}$ \\
\cline { 2 - 5 } & 5 & $192 \pm 10$ & $\mathbf{7 6 9} \pm 39$ & $\mathbf{1 2 5 0 0} \pm 625$ \\
\cline { 2 - 5 } & 10 & $192 \pm 10$ & $\mathbf{7 6 9} \pm 39$ & $6154 \pm 308$ \\
\cline { 2 - 5 } & 20 & $\mathbf{3 8 5} \pm 19$ & $192 \pm 10$ & $4200 \pm 210$ \\
\cline { 2 - 5 } & 30 & $160 \pm 8$ & $\mathrm{n} / \mathrm{d}$ & $\mathrm{n} / \mathrm{d}$ \\
\cline { 2 - 5 } & 50 & $137 \pm 7$ & $192 \pm 10$ & $\mathrm{n} / \mathrm{d}$ \\
\hline
\end{tabular}

Legend: $\mathrm{n} / \mathrm{a}$ - not determined.

The data shown in Table 3, indicate that in the process of $A$. calcoaceticus IMV B-7241 cultivation in media \# 1 and $\# 3$, the activity of PEP-carboxylase (an enzyme that catalyzes the formation of oxaloacetate, a gluconeogenic precursors) was $1.8-2.8$ times higher than on the basal medium. At the same time, an increase in PEP-carboxylase activity correlated with the activity of PEP-carboxykinase, a corresponding enzyme of gluconeogenesis, and trehalose phosphate synthase, a key enzyme of trehalose mycolate biosynthesis. Thus, under the cultivation of the IMV B-7241 strain in media \# 1 and \# 3, the activity of these enzymes was 4-6.5 and 2.1-2.6 times higher, respectively, than on the basal medium. $\mathrm{NADP}^{+}$-dependent glutamate dehydrogenase activity was increased compared to that on the basal medium only under A. calcoaceticus IMV B-7241 cultivation in medium \# 1. 
Table 2

The effect of monovalent cations present in the cultivation medium of $A$. calcoaceticus IMV B-7241 on the surfactants synthesis

\begin{tabular}{|l|c|c|c|}
\hline \multirow{2}{*}{ Medium } & \multicolumn{2}{|c|}{ Content in medium $\mathrm{g} / \mathrm{l}$} & \multirow{2}{*}{ Concentration of synthesized surfactants, $\mathrm{g} / \mathrm{l}$} \\
\cline { 2 - 3 } & $\mathrm{NaCl}$ & $\mathrm{KCl}$ & $3.6 \pm 0.18$ \\
\hline Basal & 1.0 & 0 & $6.1 \pm 0.30$ \\
\hline$\# 1$ & 0 & 0 & $2.4 \pm 0.13$ \\
\hline$\# 2$ & 2.0 & 0 & $7.7 \pm 0.35$ \\
\hline$\# 3$ & 1.0 & 1.0 & \\
\hline
\end{tabular}

Table 3

Activity of glyco- and aminolipids biosynthesis enzymes of $\boldsymbol{A}$. calcoaceticus IMV B-7241 under various cultivation conditions

\begin{tabular}{|c|c|c|c|c|}
\hline \multirow{2}{*}{ Enzyme activity (nmol·min ${ }^{-1} \cdot \mathrm{mg}^{-1}$ of protein) } & \multicolumn{4}{|c|}{ Cultivation medium } \\
\cline { 2 - 5 } & basal & $\# 1$ & $\# 2$ & $\# 3$ \\
\hline NADP $^{+}$-dependent glutamate dehydrogenase & $185 \pm 9$ & $364 \pm 18$ & $185 \pm 9$ & $145 \pm 7$ \\
\hline PEP-carboxylase & $385 \pm 19$ & $1071 \pm 54$ & $385 \pm 19$ & $690 \pm 35$ \\
\hline PEP-carboxykinase & $385 \pm 19$ & $1538 \pm 77$ & $345 \pm 17$ & $2500 \pm 125$ \\
\hline PEP synthetase & $8929 \pm 447$ & $11923 \pm 596$ & $10690 \pm 534$ & $11923 \pm 595$ \\
\hline Trehalose phosphate synthase & $145 \pm 7$ & $306 \pm 15$ & $186 \pm 9$ & $370 \pm 19$ \\
\hline
\end{tabular}

Legend: The composition of modified media \# 1-3 is shown in Table 2.

In further studies, the antimicrobial and antiadhesive activity (including the ability to destroy biofilms) of surfactants synthesized in media with different content of monovalent cations was analyzed.

Data on the MIC of surfactants obtained on the basal and modified media are given in Table 4. These results show that under cultivation of A. calcoaceticus IMV B-7241 in media \# 1-3 surfactants were synthesized, the antimicrobial activity of which in relation to the studied testcultures was significantly lower compared to the activity of surfactants obtained on the basal medium. Thus, the MIC for bacteria and fungi of surfactants synthesized on modified media were 2-3 orders of magnitude higher than those established for surfactants formed on the basal medium.

The data on the adhesion of bacterial testcultures on materials pre-treated with surfactant solutions synthesized in a medium with different content of monovalent cations are presented in Table 5.

It was found that surfactants obtained in modified media \# 1 and \# 2 were characterized by lower anti-adhesive activity than those synthesized in the basal medium. Thus, in the case of treatment of abiotic materials with solutions

Table 4

Antimicrobial activity of $A$. calcoaceticus IMV B-7241 surfactants, synthesized in the medium with different content of potassium and sodium cations

\begin{tabular}{|l|c|c|c|c|}
\hline \multirow{2}{*}{ Test-culture } & \multicolumn{4}{|c|}{$\begin{array}{c}\text { Minimum inhibitory concentrations of surfactants }(\mu \mathrm{g} / \mathrm{ml}) \text { synthesized } \\
\text { in the medium }\end{array}$} \\
\cline { 2 - 5 } & Basal & $\# 1$ & $\# 2$ & $\# 3$ \\
\hline Pseudomonas sp. MI-2 & 14 & 384 & 18 & 60 \\
\hline Staphylococcus aureus BMS-1 & 0.88 & 24 & 576 & 480 \\
\hline Escherichia coli IEM-1 & 0.88 & 24 & 144 & 480 \\
\hline Bacillus subtilis BT-2 & 1.75 & 384 & 18 & 60 \\
\hline Enterobacter cloaceae C-8 & 0.88 & 48 & 72 & 480 \\
\hline Candida albicans D-6 & 28 & $>768$ & 144 & $>960$ \\
\hline Rhizopus nigricans P1 & 56 & 384 & $>1152$ & $>960$ \\
\hline Aspergillus niger P-3 & 0.88 & 1.5 & 144 & 120 \\
\hline Fusarium culmorum T-7 & 3.5 & 48 & $>1152$ & 240 \\
\hline
\end{tabular}

Legend: the composition of modified media \# 1-3 is shown in Table 2. When determining the MIC, the error did not exceed $5 \%$. 
of such surfactants, the adhesion of bacteria and fungi was on average 10-20\% higher than after surface treatment with surfactants synthesized in a basal medium. It should be noted that after surface treatment with surfactant solutions obtained in medium \# 3, the adhesion of test-cultures decreased by only $3-10 \%$ compared to the using surfactants synthesized in the basal medium.

The data on the destruction of bacterial and yeast biofilms by surfactants obtained in basal and modified media are presented in Table 6. Degree of $S$. aureus BMS-1 and C. albicans D-6 biofilm destruction was the lowest (6-22\%) in terms of the action of surfactant solutions synthesized in medium \# 3, and this pattern was observed for surfactants in the studied range of their concentrations $(37-296 \mu \mathrm{g} / \mathrm{ml})$. At the same time, in the presence of such surfactants, $B$. subtilis BT-2 biofilm destruction was the highest and reached 50-53\%. It should be noted that the degree of testcultures biofilms destruction under the action of surfactants (37-74 $\mu \mathrm{g} / \mathrm{ml})$ synthesized in media \# 1 and \# 2 differed slightly (only by a few percent) from destruction in the presence of similar concentrations of surfactant solutions obtained in the basal medium.

\section{Table 5}

Bacterial adhesion on abiotic surfaces treated with surfactant solutions synthesized by $A$. calcoaceticus IMV B-7241 under various cultivation conditions

\begin{tabular}{|l|c|c|c|c|c|}
\hline \multirow{3}{*}{ Test-culture } & $\begin{array}{c}\text { Cultivation } \\
\text { medium }\end{array}$ & \multicolumn{4}{|c|}{ Adhesion, \% } \\
\cline { 2 - 6 } & glass & tile & steel & poly-styrene \\
\hline \multirow{4}{*}{ Staphylococcus aureus BMS-1 } & Basal & 58 & 71 & 26 & 75 \\
\cline { 2 - 6 } & $\# 1$ & 58 & 92 & 50 & 90 \\
\cline { 2 - 6 } & $\# 2$ & 87 & 90 & 67 & 95 \\
\hline \multirow{4}{*}{ Bacillus subtilis BT-2 } & $\# 3$ & 62 & 70 & 36 & 78 \\
\cline { 2 - 6 } & Basal & 68 & 38 & 26 & 70 \\
\cline { 2 - 6 } & $\# 1$ & 78 & 61 & 50 & 83 \\
\cline { 2 - 6 } & $\# 2$ & 75 & 62 & 61 & 85 \\
\cline { 2 - 6 } & $\# 3$ & 56 & 48 & 36 & 79 \\
\cline { 2 - 6 } & Basal & 65 & 53 & 48 & 68 \\
\cline { 2 - 6 } & $\# 2$ & 78 & 63 & 68 & 81 \\
\cline { 2 - 6 } & $\# 3$ & 58 & 70 & 81 & 72 \\
\hline \multirow{3}{*}{ Aspergillus niger P-3 } & Basal & 76 & $\mathrm{n} / \mathrm{d}$ & $\mathrm{n} / \mathrm{d}$ & 60 \\
\cline { 2 - 6 } & $\# 1$ & 90 & $\mathrm{n} / \mathrm{d}$ & $\mathrm{n} / \mathrm{d}$ & 79 \\
\cline { 2 - 6 } & $\# 2$ & 86 & $\mathrm{n} / \mathrm{d}$ & $\mathrm{n} / \mathrm{d}$ & 75 \\
\cline { 2 - 6 } & $\# 3$ & 82 & $\mathrm{n} / \mathrm{d}$ & $\mathrm{n} / \mathrm{d}$ & 68 \\
\hline
\end{tabular}

Legend: the composition of modified media \# 1-3 is shown in Table 2. When determining adhesion, the error did not exceed $5 \%$. The concentration of surfactant solutions is $0.12 \mu \mathrm{g} / \mathrm{ml} . \mathrm{n} / \mathrm{d}$ - not determined.

Discussion. Data on inhibitory of $\mathrm{NADP}^{+}$ dependent glutamate dehydrogenase $A$. calcoaceticus IMV B-7241 activity with potassium and sodium cations in relatively high concentrations (over $50 \mathrm{mM}$, see Table 1) are consistent with the literature data $[13,14]$. Thus, in the presence of $1 \mathrm{M}$ of potassium chloride, a $30 \%$ decrease in the activity of the purified enzyme was observed in hyperthermophilic archaea Thermococcus waiotapuensis [13], the activity of purified $\mathrm{NADP}^{+}$-dependent glutamate dehydrogenase of Pyrobaculum calidifontis was inhibited by $50 \%$ in the presence of 100-200 $\mathrm{mM}$ of potassium chloride and 100-300 $\mathrm{mM}$ of sodium chloride [14].

In this regard, it was suggested that the exclusion from the cultivation medium of $A$. calcoaceticus
IMV B-7241 of sodium cations (medium \# 1) will be accompanied by the synthesis of surfactants with increased antimicrobial activity, and an increase in medium of sodium cations (medium \# 2) or potassium and sodium cations (medium \# 3) will be accompanied by the formation of surfactants with low antimicrobial activity. However, the results obtained were unexpected: the surfactants synthesized by IMV B-7241 strain in media \# 1-3 were characterized by low antimicrobial activity in contrast to the surfactants obtained in the basal medium (see Table 4). Since the basal medium contains $1 \mathrm{~g} / 1$ of $\mathrm{NaCl}$ (or $17 \mathrm{mM}$ ), it was suggested that at low concentrations, sodium cations may be activators of $\mathrm{NADP}^{+}$-dependent glutamate dehydrogenase, a key enzyme in the 
biosynthesis of aminolipids responsible for the antimicrobial activity of the surfactant complex. Further experiments confirmed our assumption (see Table 1): in the presence of 5 and $10 \mathrm{mM} \mathrm{Na}^{+}$ in a reaction mixture, the activity of this enzyme doubled compared to that without sodium cations, which can explain the high antimicrobial activity of surfactants synthesized in the basal medium.

Table 6

The effect of surfactants synthesized by $A$. calcoaceticus IMV B-7241 under various cultivation conditions on biofilm destruction

\begin{tabular}{|l|c|c|c|c|c|}
\hline \multirow{3}{*}{ Test culture } & $\begin{array}{c}\text { Cultivation } \\
\text { medium }\end{array}$ & \multicolumn{3}{|c|}{ Biofilm destruction (\%) at surfactant concentration $(\mu \mathrm{g} / \mathrm{ml})$} \\
\cline { 3 - 6 } & Basal & 37 & 74 & 148 & 296 \\
\hline \multirow{4}{*}{ Staphylococcus aureus BMS-1 } & 36 & 38 & 57 & 66 \\
\cline { 2 - 6 } & $\# 1$ & 27 & 36 & 35 & 36 \\
\cline { 2 - 6 } & $\# 2$ & 34 & 31 & 14 & 6 \\
\hline \multirow{4}{*}{ Bacillus subtilis BT-2 } & $\# 3$ & 6 & 13 & 18 & 21 \\
\cline { 2 - 6 } & Basal & 19 & 39 & 45 & 46 \\
\cline { 2 - 6 } & $\# 1$ & 23 & 40 & 45 & 48 \\
\cline { 2 - 6 } & $\# 2$ & 22 & 45 & 47 & 45 \\
\cline { 2 - 6 } & $\# 3$ & 53 & 50 & 51 & 52 \\
\cline { 2 - 6 } & Basal & 24 & 33 & 39 & 44 \\
\cline { 2 - 6 } & $\# 1$ & 24 & 33 & 46 & 47 \\
\cline { 2 - 6 } & $\# 2$ & 27 & 36 & 45 & 47 \\
\hline
\end{tabular}

Legend: the composition of modified media \# 1-3 is shown in Table 2. When determining the destruction, the error did not exceed $5 \%$.

Other unexpected results were data on the concentration of surfactants synthesized under cultivation of $A$. calcoaceticus IMV B-7241 in media with different content of monovalent cations (see Table 2). It turned out that during the IMV B-7241 strain cultivation in a medium without $\mathrm{NaCl}$ (medium \# 1) and in a medium containing $1 \mathrm{~g} / 1$ of potassium chloride and sodium chloride (medium \# 3), the surfactant concentration was the highest $(6.1-7.7 \mathrm{~g} / 1)$. Since the synthesized surfactants showed low antimicrobial activity, it was assumed that under such conditions, surfactant glycolipids are mainly synthesized. The data shown in Table 1 indicate that potassium cations in low concentrations ( 5 and $10 \mathrm{mM}$ ) are activators of key enzymes of glycolipids biosynthesis (PEP-carboxykinase and PEP-synthetase). Therefore, an increase in the concentration of synthesized surfactants during cultivation of IMV B-7241 strain in medium 1 (without sodium chloride) may be precisely because of an increased synthesis under such conditions of glycolipids. At the same time, sodium cations in low concentrations $(5-20 \mathrm{mM})$ are activators of glycolipids biosynthesis enzymes. Therefore, an increase in the concentration of synthesized surfactants when the strain was grown in medium \# 3 (contains $1 \mathrm{~g} / 1$ of potassium chloride and sodium chloride) may be due to an increase in synthesis under such conditions of cultivation of both glycolipids and aminolipids (since the activity of $\mathrm{NADP}^{+}$-glutamate dehydrogenase increases at low concentrations of sodium cations). However, since the antimicrobial activity of such surfactants was low, it can be assumed that the complex is dominated by glycolipids or neutral lipids, where monovalent cations in low concentrations can also be the activator of their synthesis.

Such conclusions were also supported by data on determining the activity of aminolipids and glycolipids biosynthesis enzymes during the IMV B-7241 strain cultivation in media with different content of monovalent cations (see Table 3 ). During A. calcoaceticus IMV B-7241 cultivation in media \# 1 and \# 3, the activity of glycolipids biosynthesis enzymes (PEP-carboxylase, PEPcarboxykinase, PEP-synthetase, and trehalose phosphate synthetate) was significantly higher than on the basal medium.

It should be noted that low antimicrobial activity of surfactants synthesized by IMV B-7241 strain in the medium \# 2 (see Table 4) can also be explained by an increase in synthesis under such conditions of glycolipids: the activity of PEP-synthetase and trehalose phosphate synthase is 1.2 and 1.3 fold higher than on the basal medium. 
One of the mechanisms underlying the antiadhesive activity of surfactants is the antimicrobial activity of surfactants [2-4]. It is quite probable that it is precisely the low antimicrobial activity of surfactants synthesized by $A$. calcoaceticus IMV B-7241 in media \# 1-3 is one of the reasons for the lower anti-adhesive activity of such surfactants and their ability to destroy biofilms (see Tables 5 and 6).

The results presented in this article are a continuation of our previous studies $[5,6,11]$ on the possibility of regulating the antimicrobial and anti-adhesive activity of biosurfactants during the cultivation of a producer in a modified medium containing activators/inhibitors of enzymes responsible for the synthesis of components of the surfactants complex, which have certain biological properties. However, in our previous papers (unlike this article), the point at issue was increasing the antimicrobial and anti-adhesive activity of surfactants $A$. calcoaceticus IMV B-7241, Rhodococcus erythropolis IMV Ac5017 and Nocardia vaccinii IMV B-7405. At the same time, the data in Table 1 on the activation of $\mathrm{NADP}^{+}$-dependent glutamate dehydrogenase of the IMV B-7241 strain in the presence of low concentrations of monovalent cations, suggestive of the introduction of less than 1-2 g/l concentrations of sodium and potassium cations into the cultivation medium will be accompanied by the synthesis of surfactants with high antimicrobial and antiadhesive activity. Our further research will be devoted to this issue clarification.

In paper [11], we summarized both our own experimental data on the regulation of the biological activity of biosurfactants, and some literature data on the effect of certain cations in nutrient media on the synthesis of both surfactants and other products of microbial synthesis.

Let's briefly analyze the studies that were not mentioned in our previous papers. We will compare the results obtained with the literature data in two directions: the effect of cations on the activity of $\mathrm{NADP}^{+}$-glutamate dehydrogenase in various microorganisms and the effect of cations on the synthesis of microbial-derived surfactants.

It is known from the literature that monovalent cations can be both inhibitors [13, 14] and activators of $\mathrm{NADP}^{+}$-glutamate dehydrogenase $[7,8]$. In paper [15] it is noted that the stability of Escherichia coli glutamate dehydrogenase increased in the presence of lithium cations at concentrations from 1 to $10 \mathrm{mM}$.
Our studies [11] showed that potassium and sodium cations are activators of $\mathrm{NADP}^{+}$glutamate dehydrogenase in the Nocardia vaccinii IMV B-7405 surfactant producer. Additional introduction of $0.5-1.0 \mathrm{~g} / 1$ of sodium chloride, potassium chloride or a mixture of them in the cultivation medium of the strain IMV B-7405 was accompanied by the synthesis of surfactants, the MIC of which relative to bacterial and yeast testing cultures were 2-125 and 2-30 fold lower, respectively, the adhesion of bacteria on abiotic materials treated with such surfactants is 1.1-1.6 fold lower, and the degree of destruction of yeast biofilms is $25-48 \%$ higher compared to the indicators to established for surfactants obtained in the basal medium.

In the same manner as monovalent, divalent cations can be both activators and inhibitors of $\mathrm{NADP}^{+}$-glutamate dehydrogenase activity in microorganisms [16, 17]. Geotrichum candidum S12 glutamate dehydrogenase is unique, as it is characterized by substrate specificity for glutamate, 2-oxoglutarate, hexanol, and isoamil alcohol (3-methyl 1-butanol) [17]. In the presence of adenosine diphosphoric acid, $\mathrm{Fe}^{2+}, \mathrm{K}^{+}$, and $\mathrm{Zn}^{2+}$, an increase in enzymatic activity relative to hexanol was observed, and in the presence of EDTA, $\mathrm{Mn}^{2+}$, and adenosine triphosphoric acid, its inhibition was observed. Ferrous cations at a concentration of 1 $\mathrm{mM}$ increased the activity of $\mathrm{NADP}^{+}$-glutamate dehydrogenase in Klebsiella pneumoniae F-5-2 by $10 \%[16]$.

In most studies on the effect of trace elements in the composition of nutrient media on the surfactant synthesis, the authors only state one or another effect of certain cations, without discussing possible mechanisms of such an effect on the formation of the final product [18-21].

In literature [22-24], a positive effect of divalent cations (ferrum, manganese, magnesium) on surfactin synthesis by representatives of the genus Bacillus is reported. Thus, the introduction of ferrous sulfate $(2 \mathrm{mM})$, magnesium sulfate $(0.8 \mathrm{mM})$, and manganese sulfate $(0.2 \mathrm{mM})$ into the cultivation medium of Bacillus subtilis \#573 was accompanied by increasing the surfactants synthesis to $4.829 \mathrm{~g} / 1$ (in the medium without these cations $-1.311 \mathrm{~g} / \mathrm{l}$ ) [22]. The authors of this paper note that ferrum, manganese, and magnesium cations are cofactors of surfactin biosynthesis enzymes. If the concentration of manganese cations increases to $0.1 \mathrm{mM}$ in the B. subtilis ATCC 21332 cultivation medium, 
a 6.2-fold increase in surfactant concentration (up to $1500 \mathrm{mg} / \mathrm{l}$ ) was observed due to the participation of $\mathrm{Mn}^{2+}$ in the mobilization of glutamate synthase activity, which enhances nitrogen metabolism, resulting in more free amino acids formation for surfactin synthesis [23]. Introduction in B. subtilis SZMC 6179J cultivation medium of manganese, copper, and nickel cations at a concentration of $1 \mathrm{mM}$ was accompanied by the synthesis of methyl eterified forms of surfactin and new variants of this lipopeptide with a $\mathrm{C} 15-\mathrm{C} 18$ chain acyl length [24]. The authors plan to further study the biological activity of such surfactins.

In 2020, a paper was published [25], which reports the activation of rhla and $r h l B$ genes of RHA-C10-C10 monorhamnolipid biosynthesis by ferrous cations $(0.05 \mathrm{~g} / 1)$.

In data [18-20, 22-25], traditional substrates (mainly carbohydrates, as well as n-paraffines, corn steep extract) were used as carbon sources for the cultivation of surfactant producers. Luo with coauthors [25] found that the introduction of $6.4 \mathrm{~g} / 1$ $\mathrm{NaNO}_{3}$ and $3.1 \mathrm{~g} / 1 \mathrm{MgSO}_{4}$ into the Pseudomonas aeruginosa ATCC 9027 cultivation medium with refried oil allowed to increase the synthesis of rhamnolipids to $8.5 \mathrm{~g} / 1$, which is 1.4 fold higher than on the basal medium. However, in this paper, the authors did not explain or discuss possible mechanisms of the positive effect of magnesium or sodium cations on surfactant synthesis.

It should be noted that in the available literature we were not able to find information on the dependence of the biological activity of surfactants on the content of monovalent cations in the producer culture medium.

So, the results of this study are consistent with the data of our previous studies on the possibility of regulating the antimicrobial and anti-adhesive activity of surfactants in the process of producer cultivation by changing in the medium the content of cations, which are inhibitors/activators of enzymes responsible for the synthesis of components of the surfactants complex, which have certain biological properties.
СИНТЕЗ ТА БІОЛОГІЧНА

АКТИВНІСТЬ ПОВЕРХНЕВО-

АКТИВНИХ РЕЧОВИН

ACINETOBACTER CALCOACETICUS

ІМВ В-7241 ЗАЛЕЖНО ВІД ВМІСТУ

ОДНОВАЛЕНТНИХ КАТІОНІВ

У СЕРЕДОВИЩІ КУЛЬТИВУВАННЯ

\author{
Т.П. Пирог ${ }^{1,2}$, Д.А. Луцай ${ }^{1}$, \\ Т.А. Шевчук ${ }^{2}$, Г.О. Уутинська
}

${ }^{1}$ Національний університет харчових технологій, вул. Володимирська, 68, Київ, 01601, Україна

${ }^{2}$ Інститут мікробіології і вірусології ім. Д.К. Заболотного НАН Украӥни, вул. Академіка Заболотного, 154, Київ, 03143, Україна

\section{Резюме}

Мікробні поверхнево-активні речовини (ПАР) $\epsilon$ препаратами мультифункціонального призначення завдяки комплексу фізико-хімічних (зниження поверхневого та міжфазного натягу, емульгувальна активність) та біологічних (антимікробна та антиадгезивна активності, здатність до руйнування біоплівок) властивостей . Проте недоліком ПАР, що синтезуються у вигляді комплексу сполук, є можливість зміни біологічної активності залежно від умов культивування продуцента. Мета. Дослідити вплив катіонів калію та натрію на НАД $\Phi^{+}$-залежну глутаматдегідрогеназну активність безклітинного екстракту Acinetobacter calcoaceticus IMB B-7241 з наступною відповідною модифікацією складу поживного середовища і визначенням антимікробної та антиадгезивної активності синтезованих ПАР. Методи. Штам A. calcoaceticus IMB В-7241 вирощували у середовищах, що містили як джерело вуглецю $2 \%$ відпрацьованої соняшникової олії, а також різні концентрації хлориду калію і натрію (базове - 1,0 $\mathrm{NaCl}$ г/л, середовище 1 , що не містило $\mathrm{NaCl}$, середовище 2, в якому концентрація $\mathrm{NaCl}$ становила 2,0 г/л, середовище 3 , в якому концентрація $\mathrm{NaCl}$ i $\mathrm{KCl}$ становила по 1,0 г/л). ПАР екстрагували 3 супернатанту культуральної рідини модифікованою сумішшю Фолча. Антиадгезивну активність та ступінь деструкції біоплівок визначали спектрофотометричним методом, антимікробну активність - за показником мінімальної інгібуючої концентрації (МІК). Активність ферментів біосинтезу поверхнево-активних аміноліпідів (НАД $\Phi^{+}$-залежна глутаматдегідрогеназа) та гліколіпідів (фосфоенолпіруват(ФЕП)-карбоксилаза, 
ФЕП-синтетаза, ФЕП-карбоксикіназа, трегалозофосфатсинтаза) аналізували у безклітинних екстрактах, одержаних після руйнування клітин ультразвуком. Результати. Встановлено, що катіони калію і натрію у концентраціях 50 і 100 мМ є інгібіторами НАД $\Phi^{+}$-залежної глутаматдегідрогенази, а в нижчих концентраціях (5-20 мМ) - активаторами цього ферменту, а також ФЕП-карбоксикінази і ФЕП-синтетази. Збільшення концентрації ПАР до 6,1-7,7 г/л під час культивування A. calcoaceticus IMB B-7241 у середовищі 1 і 3 зумовлено переважним синтезом за таких умов гліколіпідів, про що свідчило підвищення в 1,8-6,5 разів активності ФЕП-карбоксилази, ФЕП-карбоксикінази, ФЕПсинтетази і трегалозофосфатсинтази порівняно 3 показниками на базовому середовищі. Концентрація ПАР, синтезованих на базовому середовищі, становила 3,6 г/л, проте такі поверхнево-активні речовини характеризувалися найвищою антимікробною та антиадгезивною активністю. Їх мінімальні інгібуючі концентрації щодо досліджуваних тест-культур бактерій (Pseudomonas sp. MI-2, Bacillus subtilis БТ-2, Escherichia coli IEM-1, Staphylococcus aureus БMC-1, Enterobacter cloaceae C-8) і грибів (Candida albicans Д-6, Rhizopus nigricans P1, Aspergillus niger P-3, Fusarium culmorum T-7) становили 0,88-56 мкг/мл

1. Singh P, Patil Y, Rale V. Biosurfactant production: emerging trends and promising strategies. J Appl Microbiol. 2019; 126(1):2-13. doi: 10.1111/jam.14057.

2. Naughton PJ, Marchant R, Naughton V, Banat IM. Microbial biosurfactants: current trends and applications in agricultural and biomedical industries. J Appl Microbiol. 2019; 127(1):12-28. doi: $10.1111 /$ jam. 14243 .

3. Malviya D, Sahu PK, Singh UB, Paul S, Gupta A, Gupta AR, et al. Lesson from Ecotoxicity: Revisiting the Microbial Lipopeptides for the Management of Emerging Diseases for Crop Protection. Int J Environ Res Public Health. 2020; 17(4):1434. doi: 10.3390/ijerph17041434.

4. Herzog M, Tiso T, Blank LM, Winter R. Interaction of rhamnolipids with model biomembranes of varying complexity. Biochim Biophys Acta Biomembr. 2020; 1862(11):183431. doi: 10.1016/j.bbamem.2020.183431. i були на 2-3 порядки нижчими порівняно з показниками, встановленими для ПАР, синтезованих на модифікованих середовищах 1-3. У разі обробки абіотичних матеріалів розчинами поверхнево-активних речовин, одержаних на базовому середовищі, адгезія бактерій і грибів була в середньому на 10-20 \% нижчою, ніж після обробки поверхонь синтезованими на модифікованих середовищах ПАР. За наявності 148-296 мкг/мл ПАР, одержаних на базовому середовищі, ступінь руйнування біоплівок S. aureus БМС-1 і B. subtilis БТ-2 становив 45-66, а дріжджів C. albicans Д-6 - 3944 \%. За дії аналогічних концентрацій ПАР, синтезованих на модифікованих середовищах, деструкція бактеріальних і дріжджової біоплівок була нижчою: 6-52 і 20-46 \% відповідно. Висновки. Одержані результати узгоджуються 3 даними наших попередніх досліджень про можливість регуляції антимікробної та антиадгезивної активності ПАР в процесі культивування продуцента шляхом зміни у складі середовища вмісту катіонів, які $є$ інгібіторами/активаторами ферментів, відповідальних за синтез складових комплексу ПАР, яким притаманні певні біологічні властивості.

Ключові слова: Acinetobacter calcoaceticus IMB B-7241, поверхнево-активні речовини, катіони калію і натрію, біологічна активність, біосинтез.

5. Pirog TP, Kliuchka LV, Shevchuk TA, Muchnyk FV. [Interrelation of Chemical Composition and Biological Properties of Microbial Surfactants]. Mikrobiol Z. 2019; 81(3):84-104. Ukrainian. doi: https://doi.org/10.15407/microbiolj81.03.084

6. Pirog TP, Sidor IV, Lutsai DA. Calcium and magnesium cations influence on antimicrobial and antiadhesive activity of Acinetobacter calcoaceticus IMV B-7241 surfactants. Biotechnologia Acta. 2016; 9(6):50-7. https://doi.org/ 10.15407/ biotech9.06.050.

7. Bhuiya MW, Sakuraba H, Kujo C, Nunoura-Kominato N, Kawarabayasi Y, Kikuchi H, et al. Glutamate dehydrogenase from the aerobic hyperthermophilic archaeon Aeropyrum pernix $\mathrm{K} 1$ : enzymatic characterization, identification of the encoding gene, and phylogenetic implications. Extremophiles. 2000; 4(6):333-41. doi: $10.1007 / \mathrm{s} 007920070002$. 
8. Alba-Lois L, Segal C, Rodarte B, Valdés-López V, DeLuna A, Cárdenas R. NADP-glutamate dehydrogenase activity is increased under hyperosmotic conditions in the halotolerant yeast Debaryomyces hansenii. Curr Microbiol. 2004; 48(1):68-72. doi: 10.1007/s00284-003-4076-7.

9. Pirog TP, Nikituk LV, Iutynska GO. [Biological properties of Nocardia vaccinii IMV B-7405 surfactants synthesized on byproduct of biodiesel production]. Mikrobiol Z. 2016; 78(5):12-20. Ukrainian.

10. Pirog TP, Shevchuk TA, Voloshina IN, Gregirchak NN. Use of claydite-immobilized oil-oxidizing microbial cells for purification of water from oil. Appl Biochem Microbiol. 2005; 41(1): 51-5. https://doi.org/10.1007/s10438-0050010-z.

11. Pirog TP, Kliuchka LV, Shevchuk TA, Iutynska GO. [Influence of Monovalent Cations on Synthesis and Biological Activity of Nocardia vaccinii IMV B-7405 Surfactants]. Mikrobiol Z. 2019; 81(4):15-28. Ukrainian. doi: https://doi. org/10.15407/microbiolj81.04.015.

12. Pirog TP, Shevchuk TA, Beregova KA, Kudrya NV. [Peculiarities of glucose and glycerol metabolism in Nocardia vaccinii IMB B-7405]. Ukr Biochem J. 2015; 87(2):66-75. Ukrainian.

13. Lee MK, González JM, Robb FT. Extremely thermostable glutamate dehydrogenase (GDH) from the freshwater archaeon Thermococcus waiotapuensis: cloning and comparison with two marine hyperthermophilic GDHs. Extremophiles. 2002; 6(2):151-9. doi: 10.1007/s007920100238.

14. Wakamatsu T, Higashi C, Ohmori T, Doi K, Ohshima T. Biochemical characterization of two glutamate dehydrogenases with different cofactor specificities from a hyperthermophilic archaeon Pyrobaculum calidifontis. Extremophiles. 2013; 17(3):379-89. doi: 10.1007/s00792-013-0527-7.

15. Garcia-Galan C, Barbosa O, Fernandez-Lafuente R. Stabilization of the hexameric glutamate dehydrogenase from Escherichia coli by cations and polyethyleneimine. Enzyme Microb Technol. 2013; 52(4-5):211-7. doi: 10.1016/j. enzmictec.2013.02.014

16. Kim YJ, Yoshizawa M, Takenaka S, Murakami $\mathrm{S}$, Aoki K. Ammonia assimilation in Klebsiella pneumoniae F-5-2 that can utilize ammonium and nitrate ions simultaneously: purification and characterization of glutamate dehydrogenase and glutamine synthetase. J Biosci Bioeng. 2002; 93(6):584-8. doi: 10.1016/s13891723(02)80241-9.

17. Zhu J, Lu K, Xu X, Wang X, Shi J. Purification and characterization of a novel glutamate dehydrogenase from Geotrichum candidum with higher alcohol and amino acid activity. AMB Express. 2017; 7(1):9. doi: 10.1186/s13568-0160307-8.

18. Burgos-Díaz C, Pons R, Teruel JA, Aranda FJ, Ortiz A, Manresa A, et al. The production and physicochemical properties of a biosurfactant mixture obtained from Sphingobacterium detergens. J Colloid Interface Sci. 2013; 394:368-79. doi: 10.1016/j.jcis.2012.12.017.

19. Rekha R, Hemen S, Debahuti D. Achieving the Best Yield in Glycolipid Biosurfactant Preparation by Selecting the Proper Carbon/Nitrogen Ratio. J Surfactant Deterg. 2014; 17:563-71.

20. Joshi PA, Singh N, Shekhawat DB. Effect of metal ions on growth and biosurfactant production by Halophilic bacteria. Adv Appl Sci Res. 2015; 6:152-6.

21. Nurfarahin AH, Mohamed MS, Phang LY. Culture Medium Development for Microbial-Derived Surfactants Production - An Overview. Molecules. 2018; 23(5):1049. doi: 10.3390/molecules23051049.

22. Gudiña EJ, Fernandes EC, Rodrigues AI, Teixeira JA, Rodrigues LR. Biosurfactant production by Bacillus subtilis using corn steep liquor as culture medium. Front Microbiol. 2015; 6:59. doi: 10.3389/fmicb.2015.00059.

23. Huang X, Liu J, Wang Y, Liu J, Lu L. The positive effects of $\mathrm{Mn}^{2+}$ on nitrogen use and surfactin production by Bacillus subtilis ATCC 21332. Biotechnol Biotechnol Equip. 2015; 29(2):381-9. doi: 10.1080/13102818.2015.1006905.

24. Bartal A, Vigneshwari A, Bóka B, Vörös M, Takács I, Kredics L, et al. Effects of Different Cultivation Parameters on the Production of Surfactin Variants by a Bacillus subtilis Strain. Molecules. 2018; 23(10):2675. doi: 10.3390/ molecules 23102675 . 
25. Shatila F, Diallo MM, Şahar U, Ozdemir G, Yalçın HT. The effect of carbon, nitrogen and iron ions on mono-rhamnolipid production and rhamnolipid synthesis gene expression by Pseudomonas aeruginosa ATCC 15442. Arch Microbiol. 2020; 202(6):1407-17. doi: 10.1007/ s00203-020-01857-4.
26. Luo Z, Yuan XZ, Zhong H, Zeng GM, Liu ZF, Ma XL, et al. Optimizing rhamnolipid production by Pseudomonas aeruginosa ATCC 9027 grown on waste frying oil using response surface method and batch-fed fermentation. J Central South Univ. 2013; 20:1015-21. doi:10.1007/ s11771-013-1578-8.

Received 29.11.2020 